\title{
Silver nanoparticles selectively induce human oncogenic $\gamma$-herpesvirus-related cancer cell death through reactivating viral lytic replication
}

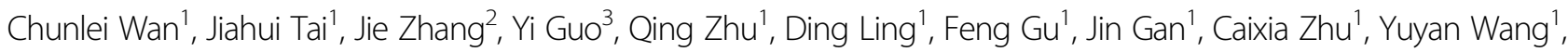 \\ Sijin Liư ${ }^{2}$ Fang Wei ${ }^{4}$ and Qiliang Cai ${ }^{1,5}$
}

\begin{abstract}
Silver nanoparticle $(\mathrm{nAg})$, which is one of the most common manufactured nanomaterials, has a wide range of biomedical applications. The human oncogenic $\gamma$-herpesviruses, Kaposi's sarcoma-associated herpesvirus (KSHV) and Epstein-Barr Virus (EBV), are etiologically linked to many malignancies. Currently, there are no efficient or specific treatments for these types of tumors, and most patients die because of resistance to conventional cytotoxic chemotherapy. Despite nAg having antitumor and antiviral activities, its effects on oncogenic herpesvirus-related cancer cells remain largely unknown. Here, we reveal that nAg presents higher cytotoxicity against KSHV- or EBVlatently infected cells via reactivating viral lytic replication, which relies on the induction of reactive oxygen species (ROS) generation and autophagy. Moreover, nAg blocks KSHV primary infection by directly destroying virion particles, as well as effectively inhibits colony formation and moderately represses the growth of KSHV-associated tumors in xenograft mouse model. Taken together, these results demonstrate the therapeutic potential of nAg for use in the antiviral infection and treatment of oncogenic herpesvirus-related cancers.
\end{abstract}

\section{Introduction}

Silver nanoparticle $(\mathrm{nAg})$ is an emerging material with a high surface area to volume ratio and unique physicochemical properties, because of its nanoscale that has shown a wide range of attractive biomedical application ${ }^{1}$. In the antiviral field, some studies have demonstrated the remarkable antiviral ability of nAg toward several viruses including human immunodeficiency virus $(\mathrm{HIV})^{2-4}$,

Correspondence: Sijin Liu (sjliu@rcees.ac.cn) or Fang Wei (fangwei@sjtu.edu.cn) or Qiliang Cai (qiliang@fudan.edu.cn)

${ }^{1}$ MOE\&NHC\&CAMS Key Laboratory of Medical Molecular Virology, School of Basic Medical Science, Shanghai Medical College, Fudan University, Shanghai 200032, P. R. China

${ }^{2}$ State Key Laboratory of Environmental Chemistry and Ecotoxcicology,

Research Center for Eco-Environmental Science, Chinese Academy of Sciences, Beijing 100085, P. R. China

Full list of author information is available at the end of the article.

These authors contributed equally: Chunlei Wan, Jiahui Tai

Edited by A. Stephanou hepatitis B virus $(\mathrm{HBV})^{5}$, herpes simplex virus $(\mathrm{HSV})^{6,7}$, and influenza virus ${ }^{8}$. Due to the complicated steps for each viral infection, the detail mechanism of $\mathrm{nAg}$ against a specific viral infection could be different. For examples, the potential mechanisms of the antiviral activity of $\mathrm{nAg}$ could be relied on either interaction with viral surface glycoproteins, competition for binding of the virus to host cells, inactivation of viral particles prior to entry, or impairing viral double-stranded DNA. However, distinct from conventional antiviral drugs, nAg can attack different viruses and a broad range of viral components, which can reduce the possibility of drug resistance. In the anticancer field, some studies have also demonstrated that $\mathrm{nAg}$ displays anticancer activity, particularly higher sensitivities of cancer cells than normal cells to $\mathrm{nAg}^{9-11}$. Importantly, some reports showed that nAg could not only prevent vascular endothelial growth factor-induced

\section{(c) The Author(s) 2019}

(c) (i) Open Access This article is licensed under a Creative Commons Attribution 4.0 International License, which permits use, sharing, adaptation, distribution and reproduction cc) in any medium or format, as long as you give appropriate credit to the original author(s) and the source, provide a link to the Creative Commons license, and indicate if changes were made. The images or other third party material in this article are included in the article's Creative Commons license, unless indicated otherwise in a credit line to the material. If material is not included in the article's Creative Commons license and your intended use is not permitted by statutory regulation or exceeds the permitted use, you will need to obtain permission directly from the copyright holder. To view a copy of this license, visit http://creativecommons.org/licenses/by/4.0/. 
(VEGF) or fibroblast growth factor-2 (FGF-2)-induced angiogenesis, which is crucial for growth and spread of tumors $^{12,13}$, but that it also significantly inhibited tumor growth in animal models ${ }^{14,15}$. However, in regard to those cancers that are associated with oncogenic virus infection, the role of $\mathrm{nAg}$ on viral-related cancer cells remains unclear.

Human oncogenic $\gamma$-herpesviruses are enveloped icosahedral double-stranded DNA viruses that include Kaposi's sarcoma-associated herpesvirus (KSHV) and Epstein-Barr virus $(E B V)^{16}$. These two $\gamma$-herpesviruses, which have been shown to infect different cell types including B cells, endothelial cells, and epithelial cells, are closely associated with many human malignancies. EBV, the first human tumor virus discovered in 1964, causes more than 200,000 cases of cancer every year ${ }^{17}$. This virus could not only primarily cause various lymphomas, including Burkitt lymphoma (BL), Hodgkins lymphoma (HL), NK-T cell lymphoma and immunodeficiency associated lymphoma, but also induce some carcinomas, such as nasopharyngeal carcinoma (NPC) and EBV-associated gastric carcinoma (EBV-GC) ${ }^{18}$. While KSHV was originally identified from Kaposi's sarcoma (KS) tissues in an AIDS patient in 1994 by Chang and Moore, and it is also associated with various lymphomas, including primary effusion lymphoma (PEL), Multicentric Castleman's disease (MCD) and KSHV-associated germinotropic lymphoproliferative disorder ${ }^{19}$. These diseases often occur in populations subject to immunosuppression, and the infection rates of KSHV are dependent on geographic location ${ }^{20}$. Like other herpesviruses, the life cycle of KSHV and EBV comprises latency and lytic replication. It has been demonstrated that KSHV/EBV-associated tumors usually harbor latent infection with limited expression of latent genes, which is closely related to tumor development, and that a few cells with spontaneous lytic replication promote viral spread and disease maintenance. To date, no standard treatments for KSHV/EBVassociated malignancies have been developed, and current treatments are suboptimal and primarily associated with toxicity. Nonspecific chemotherapeutic drugs are common clinical therapies for malignancies with KSHV/EBV infection, which usually cause considerable side effects. Considering the role of KSHV/EBV in tumors, many studies have focused on the small molecules specifically targeting viruses ${ }^{21}$. Many small molecules have been shown to either inhibit lytic replication or block the transmission of KSHV/EBV from cell to cell (which cannot clear the virus lurking in cells), or to effectively induce viral lytic replication and promote tumor cell death and exposure of the virus to host immune surveillance ${ }^{21}$. However, given that both lytic replication and constant infection of new cells contribute to viral propagation and viral pathogenesis ${ }^{22}$, agents targeting both lytic replication and viral primary infection could be promising drugs for use in treatment of KSHV/EBV-related cancers.

In this study, we explored the effects of nAg on KSHV/ EBV-associated tumor cells in vitro and in vivo. We identified spherical $\mathrm{nAg}$ with a size of $25 \mathrm{~nm}$ as an appropriate nanoparticle for induction of tumor cell cytotoxicity in a dose- and shape-dependent manner. Moreover, we demonstrated that the $25 \mathrm{~nm}$-spherical nAg-induced greater cytotoxicity in KSHV/EBV-latently infected cells through reactivating viral lytic replication, which is relied on induction of reactive oxygen species (ROS) generation and autophagy. Importantly, the $\mathrm{nAg}$ not only blocks KSHV primary infection by directly destroying virion particles, but it also effectively inhibits colony formation and moderately represses the growth of KSHV-associated PEL tumors in xenograft mouse model. This evidence suggests that nAg could be a potential agent for treating the development of oncogenic herpesvirus-associated cancers.

\section{Results}

nAg particles exert size- and shape-dependent cytotoxicity

As shown in Fig. 1a, transmission electronic microscope (TEM) was used to visualize the morphology of each polyvionylpyrolidone (PVP)-coated nAgs. To better mimic the condition in culture medium, the hydrodynamic diameter of each $\mathrm{nAg}$ in medium was also measured (Fig. 1a, bottom panel). To determine the characteristic of each PVP-coated nAg with different sizes and shapes, 293T and BJAB cells were individually used as models of the epithelium and B-lymphocyte to assess the cytotoxicity. As shown in Fig. 1b, the inhibitory effects of $\mathrm{nAg}$ on the viability of $293 \mathrm{~T}$ cells were consistent with those on BJAB cells. Among spherical shaped particles, the smaller $\mathrm{nAg}(5,25 \mathrm{~nm})$ had a stronger inhibitory effect on cell viability than the larger $\mathrm{nAg}(100,200 \mathrm{~nm})$. At a size of $100 \mathrm{~nm}$, the cytotoxicity of cubic $\mathrm{nAg}$ was greater than that of spherical nAg, which may have been because of the larger surface area (Fig. 1b). Morphological evaluation of the BJAB cells revealed that cells treated with 5 or $25 \mathrm{~nm}$ spherical $\mathrm{nAg}, 30 \mathrm{~nm}$ plate $\mathrm{nAg}$ or $100 \mathrm{~nm}$ cubic $\mathrm{nAg}$ became small and shrunken, while no significant changes were observed in cells treated with 100 or $200 \mathrm{~nm}$ spherical nAg (Fig. 1c). These findings further confirm that the cytotoxicity of nAg occurs in a size- and shapedependent manner.

\section{$\mathrm{nAg}$ induces higher cytotoxicity in KSHV/EBV-latently infected cells}

Previous studies showed that spherical nAg has significant effects and applications in many fields and can cross the plasma membrane more easily than other shapes $^{23}$, and small sized $\mathrm{nAg}$ also tends to have a greater dissolution rate than large-sized $\mathrm{nAg}^{23,24}$. Therefore, we 


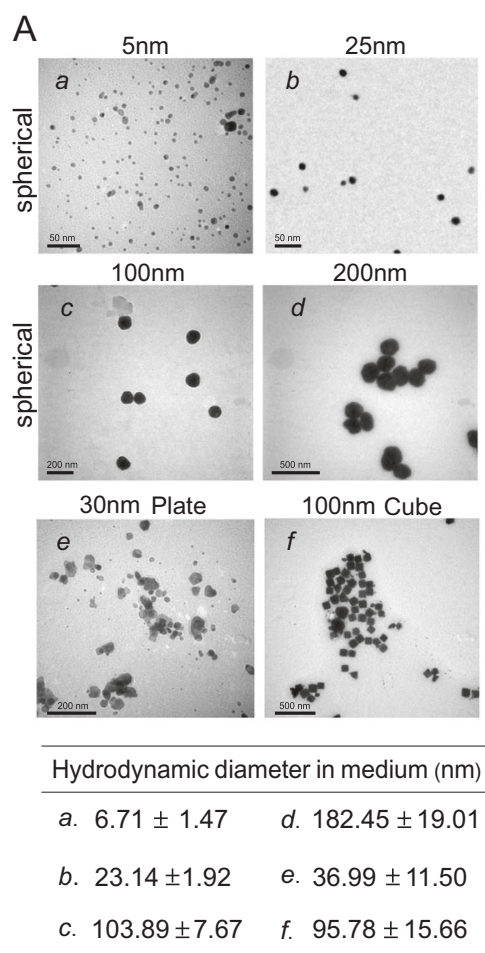

B
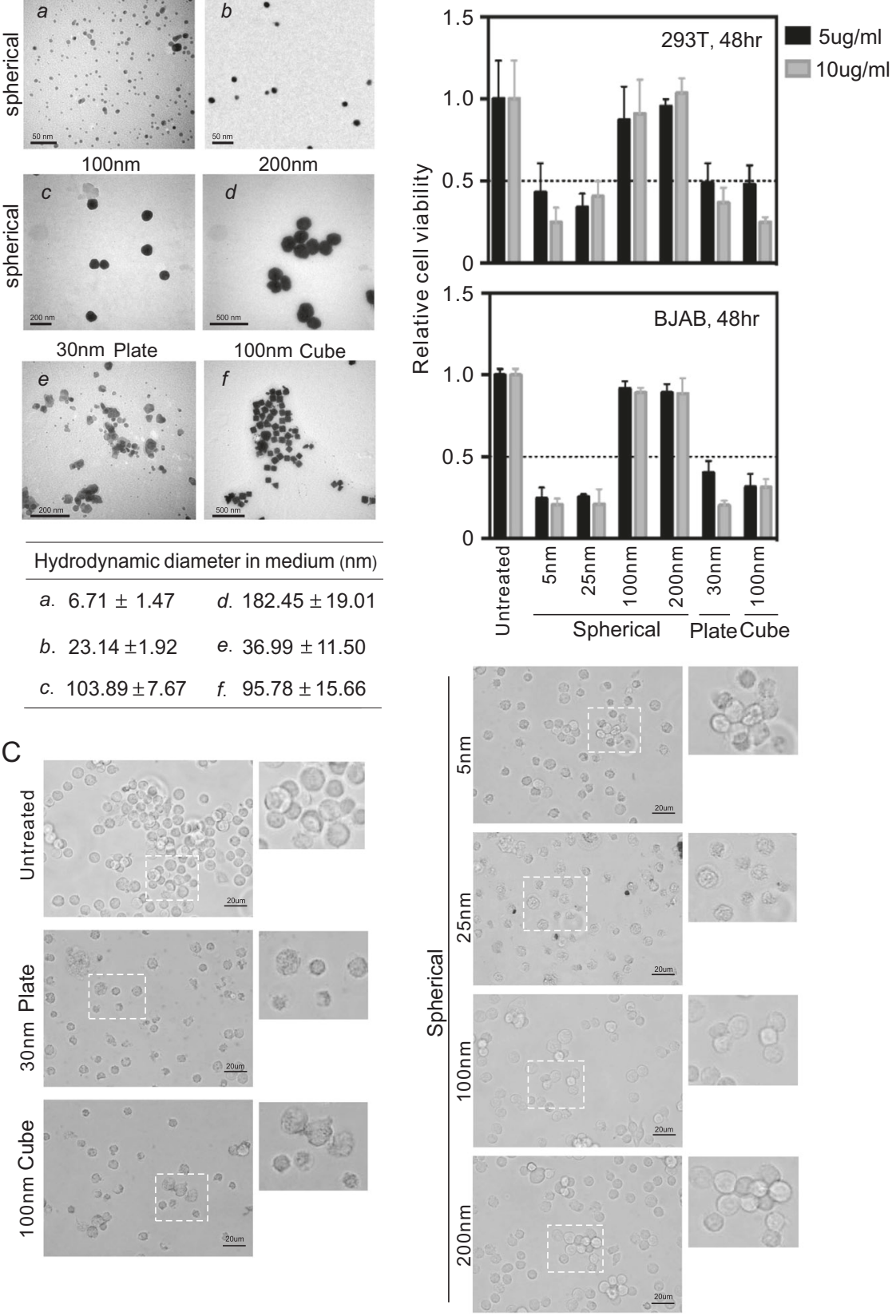

Fig. 1 nAg particles present size- and shape-dependent cytotoxicity. a Representative photograph of nAg with different size and shape under TEM. Scale bars are 50, 200, and $500 \mathrm{~nm}$ as indicated in the figure. The hydrodynamic diameter of each nAg in tissue culture medium was shown at the bottom panel. b Relative viability of $293 \mathrm{~T}$ and BJAB cells after incubation with nAg of different size and shape for $48 \mathrm{~h}$. The data shown are the means \pm SD from triplicate analyses. c The morphology of BJAB cells after $10 \mu \mathrm{g} / \mathrm{ml} \mathrm{nAg}$ treatment for $48 \mathrm{~h}$. The magnificent photograph was shown on the right panel

selected $25 \mathrm{~nm}$-spherical $\mathrm{nAg}$ for subsequent experiments. To further evaluate the inhibitory effects of $25 \mathrm{~nm}$ spherical nAg on the viral-infected B cells, different concentrations of $\mathrm{nAg}$ were used to treat $\mathrm{KSHV}$-positive (BCBL-1, BCP1) and EBV-positive (B95.8, LCL) Blymphoma cells for $48 \mathrm{~h}$. The results of a cell viability assay and morphological observation of the cytoskeleton and apoptosis showed that the $\mathrm{nAg}$ decreased cell viability in a dose-dependent manner (Fig. 2a-c). In contrast, a weaker effect was observed on primary B cells from human PBMCs, for which the relative cell viability was always higher than $80 \%$, even when it was incubated with 

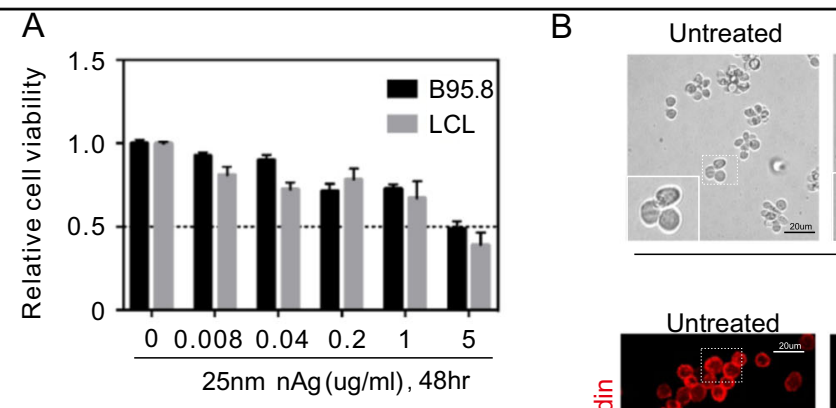

$0.2 \mathrm{ug} / \mathrm{ml}$

$1 \mathrm{ug} / \mathrm{ml}$
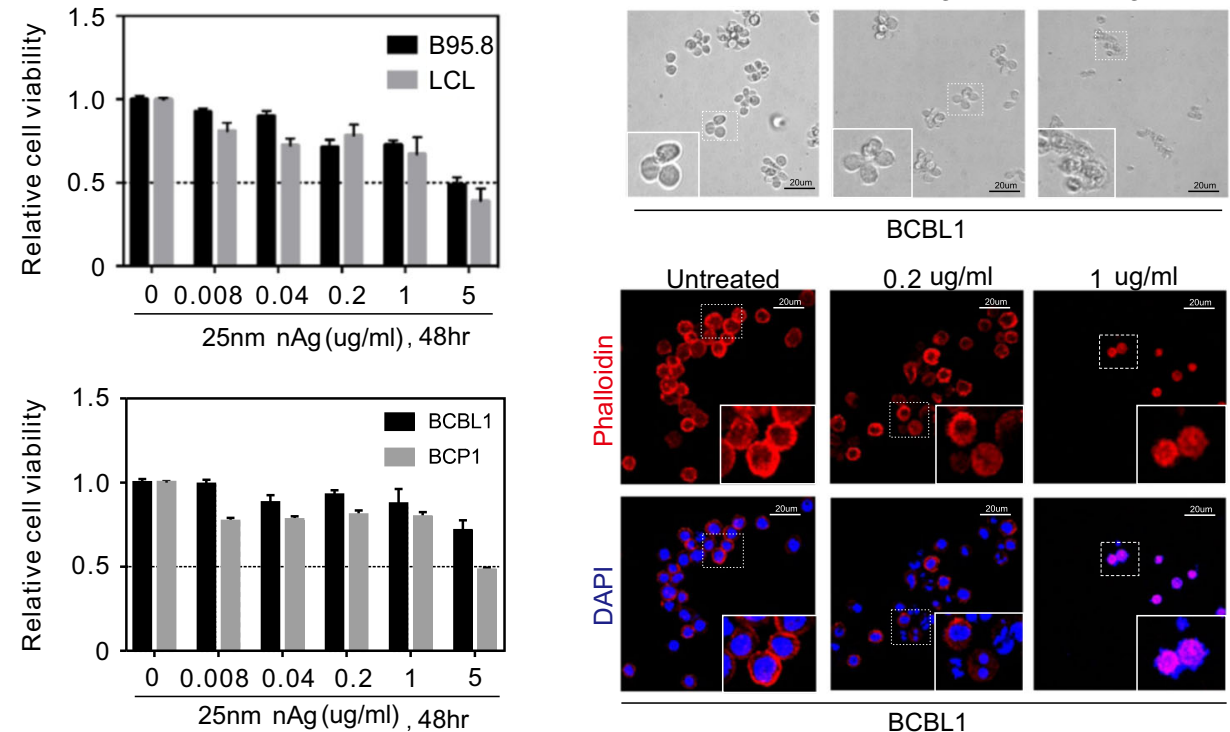

BCBL1
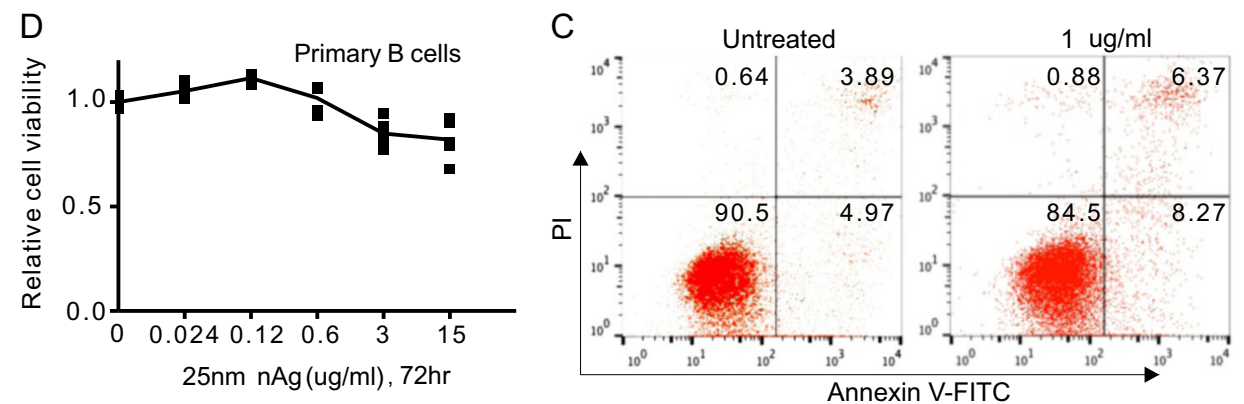

E
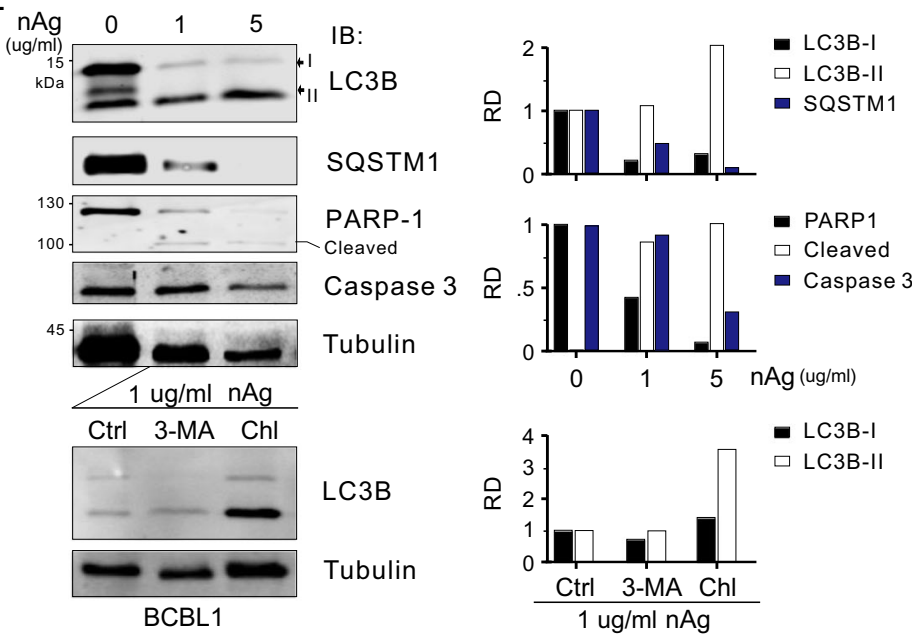

Fig. 2 nAg induces KSHV/EBV-infected cell apoptosis. a Relative viability of KSHV/EBV-infected B-lymphoma cells after $25 \mathrm{~nm}$-spherical nAg treatment. EBV-positive (B95.8, LCL) and KSHV-positive (BCBL1, BCP1) cells were subjected to cell viability assays during treatment with $25 \mathrm{~nm}$-spherical $\mathrm{nAg}$ for $48 \mathrm{~h}$. b Representative morphology of BCBL1 cells treated with nAg from a under the light microscope (top panel) and immunofluorescence microscope after TRITC-phalloidin staining (bottom panel). Nuclei are stained by DAPI. c nAg induces KSHV-infected cell apoptosis. BCBL1 cells untreated or treated with $\mathrm{nAg}(1 \mathrm{\mu g} / \mathrm{ml})$ were subjected to flow cytometry analysis with Annexin $\mathrm{V}$ and $\mathrm{PI}$ staining. The percentage of cell population was shown in the figure. $\mathbf{d}$ Relative cell viability of primary B cells from human peripheral blood mononuclear cells (PBMCs) treated with different concentrations of $25 \mathrm{~nm}$-spherical nAg for $72 \mathrm{~h}$. e Immunoblotting assays of LC3B, SQSTM1, PARP-1, and Caspase 3 in the BCBL1 cells treated with or without $25 \mathrm{~nm}$-spherical nAg from a. At $24 \mathrm{~h}$ post-treatment with $1 \mathrm{\mu g} / \mathrm{ml} \mathrm{nAg}$, cells were individually subjected to treatment with lysosomal inhibitor Choloquine (Chl, $25 \mu \mathrm{M})$ or autophagy inhibitor 3-Methyladenine (3-MA, $10 \mathrm{mM}$ ) for $1 \mathrm{~h}$, followed by immunoblotting with antibodies as indicated in the figure. Relative density (RD) of protein bands were quantified and shown on the right panel. Tubulin was used as a control 
$15 \mu \mathrm{g} / \mathrm{ml} \mathrm{nAg}$ for $72 \mathrm{~h}$ (Fig. 2d), while the relative cell viability of $\mathrm{KSHV} / \mathrm{EBV}$-infected B-lymphoma cells generally decreased to $<50 \%$ when treated with $5 \mu \mathrm{g} / \mathrm{ml} \mathrm{nAg}$ for $48 \mathrm{~h}$. Overall, these results suggest that KSHV/EBVlatently infected B-lymphoma cells were more sensitive to $\mathrm{nAg}$ than primary normal B cells.

Given that many signal pathways, including autophagy activation and apoptosis, are involved in cytotoxicity and that $\mathrm{nAg}$ has been reported to induce autophagy and apoptosis $^{25,26}$, the active markers of LC3B-II and SQSTM1 of autophagy and cleaved PARP-1 and caspase 3 of apoptosis were examined in BCBL1 cells with different dosage of $\mathrm{nAg}$ treatment. The results showed that increase of LC3B-II accumulation and PARP-1 cleavage along with decrease of SQSTM1 and caspase 3 appeared dramatically in a dose-dependent manner when cells treated with $\mathrm{nAg}$ (Fig. 2e, top panels), indicating that $\mathrm{nAg}$ could induce stronger autophagy and apoptosis in KSHVinfected cells. In addition, the results of chloroquine (lysosome inhibitor) instead of 3-MA (inhibitor of LC3B-I to II switch) treatment resulted in led to further accumulation of LC3B-II in nAg-treated cells (Fig. 2e, bottom panels), confirming that $\mathrm{nAg}$ indeed induces autophagy in KSHV-infected cells.

To further determine if nAg does have different effects on KSHV/EBV-positive and -negative tumor cells, three pairs of cell lines BJAB, iSLK and Akata with or without KSHV/EBV latent infection were individually incubated with $\mathrm{nAg}$ at different concentrations for 24 and $48 \mathrm{~h}$, after which cell viability was measured and the $50 \%$ cytotoxic concentration $\left(\mathrm{CC}_{50}\right)$ of each cell line was calculated. Interestingly, the $\mathrm{CC}_{50}$ values for $\mathrm{KSHV} /$ EBV-positive (K-BJAB, iSLK-KSHV, and Akata-EBV) cells were always consistently lower than those for KSHV/EBV-negative (BJAB, iSLK, and Akata) cells (Fig. $3 a-d)$. Further statistical analyses showed that nAg had significantly greater inhibitory effects against KSHV/ EBV-positive cells at an appropriate concentration $(3 \mu \mathrm{g} / \mathrm{ml}$ for BJAB/K-BJAB and iSLK/iSLK-KSHV, $0.6 \mu \mathrm{g} / \mathrm{ml}$ for Akata/Akata-EBV), while no significant difference were observed under the too low or too high concentrations of nAg (Fig. 3a-c). These results suggest that KSHV/EBV-latently infected cells are indeed more vulnerable to nAg than KSHV/EBV-uninfected cells within a certain concentration range.

The results from immunoblotting assays of LC3B and PARP-1 in both KSHV/EBV-positive and -negative tumor cells with or without nAg treatment, showed that LC3B-II accumulation and PARP-1 cleavage in the KSHV/EBV-infected tumor cells were consistently higher than that in the KSHV/EBV-uninfected tumor cells (Fig. $4 \mathrm{a}-\mathrm{c})$, indicating that nAg could induce stronger autophagy and apoptosis in KSHV/EBV-latently infected tumor cells.
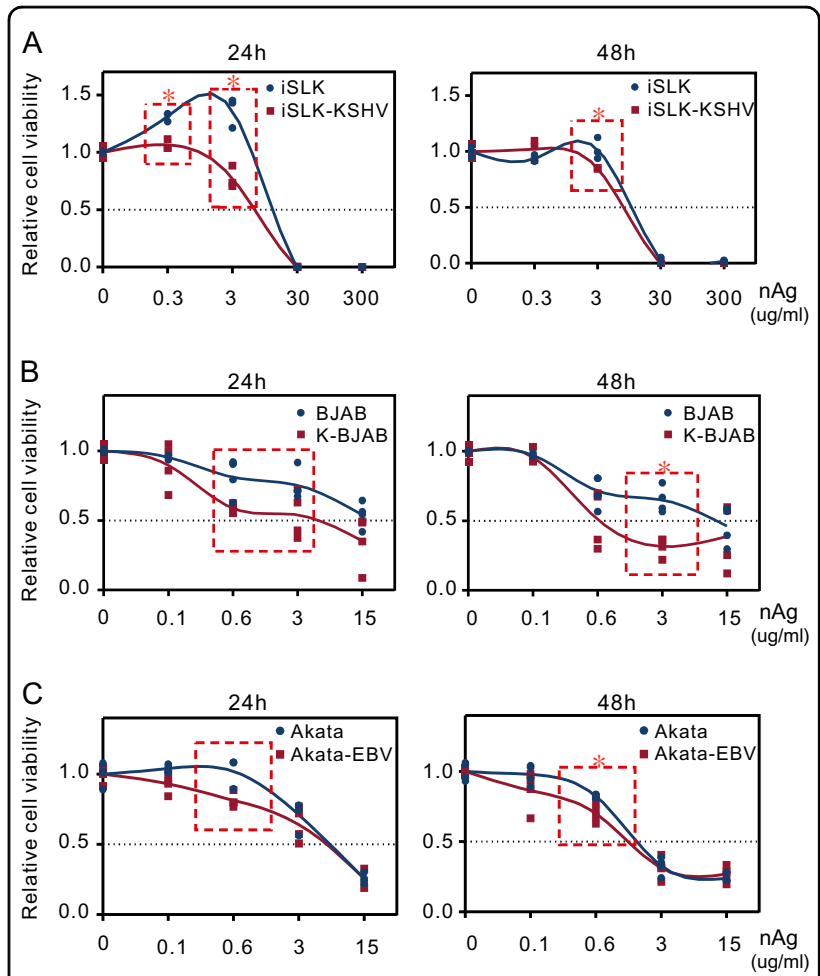

D

\begin{tabular}{ccccccc}
\hline $\begin{array}{r}\text { CC50 } \\
\text { (ug/ml) }\end{array}$ & BJAB & K-BJAB & iSLK & $\begin{array}{l}\text { iSLK- } \\
\text { KSHV }\end{array}$ & Akata & $\begin{array}{c}\text { Akata- } \\
\text { EBV }\end{array}$ \\
\hline $24 \mathrm{~h}$ & 22.86 & 3.39 & 25.98 & 3.76 & 6.43 & 5.19 \\
$48 \mathrm{~h}$ & 9.99 & 1.58 & 19.59 & 4.22 & 2.14 & 1.65
\end{tabular}

Fig. $3 \mathrm{nAg}$ presents higher cytotoxicity to KSHV/EBV-infected cells. Relative viability of $\mathbf{a}$ iSLK and iSLK-KSHV, $\mathbf{b} B J A B$ and K-BJAB, and $\mathbf{c}$ Akata and Akata-EBV cells after incubation with $25 \mathrm{~nm}$-spherical $\mathrm{nAg}$ for $24 \mathrm{~h}$ or $48 \mathrm{~h}$. The data are presented as the means \pm SD from triplicate analyses. Asterisks indicate $P$ value as follows: ${ }^{*} P<0.05$. $\mathbf{d}$ The $C_{50}$ of iSLK, iSLK-KSHV, BJAB, K-BJAB, Akata and Akata-EBV cells from $\mathbf{a}, \mathbf{b}$ and $\mathbf{c}$

\section{nAg induces ROS generation to activate KSHV/EBV lytic replication}

Since KSHV/EBV-latently infected cells present higher sensitivity to $\mathrm{nAg}$ treatment than uninfected cells. To explore whether $\mathrm{nAg}$ also induces KSHV/EBV lytic replication from latency, we treated KSHV/EBV-latently infected B-lymphoma cells with different dosages of $\mathrm{nAg}$ for $24 \mathrm{~h}$ and individually detected the mRNA transcripts of the key latent antigen LANA/EBNA1 as well as the lytic master regulator RTA/BZLF1 within the KSHV-infected (BCBL1, BCP1) and EBV-infected (B95.8, LCL) cells, along with progeny virion production. The results showed that nAg consistently increased the transcription of RTA/ BZLF1 and virion production in a dose-dependent manner, although the transcription of LANA/EBNA1 was also enhanced to some extent (Fig. 5a, b). The results of immunoblotting assays showed that the protein levels of 


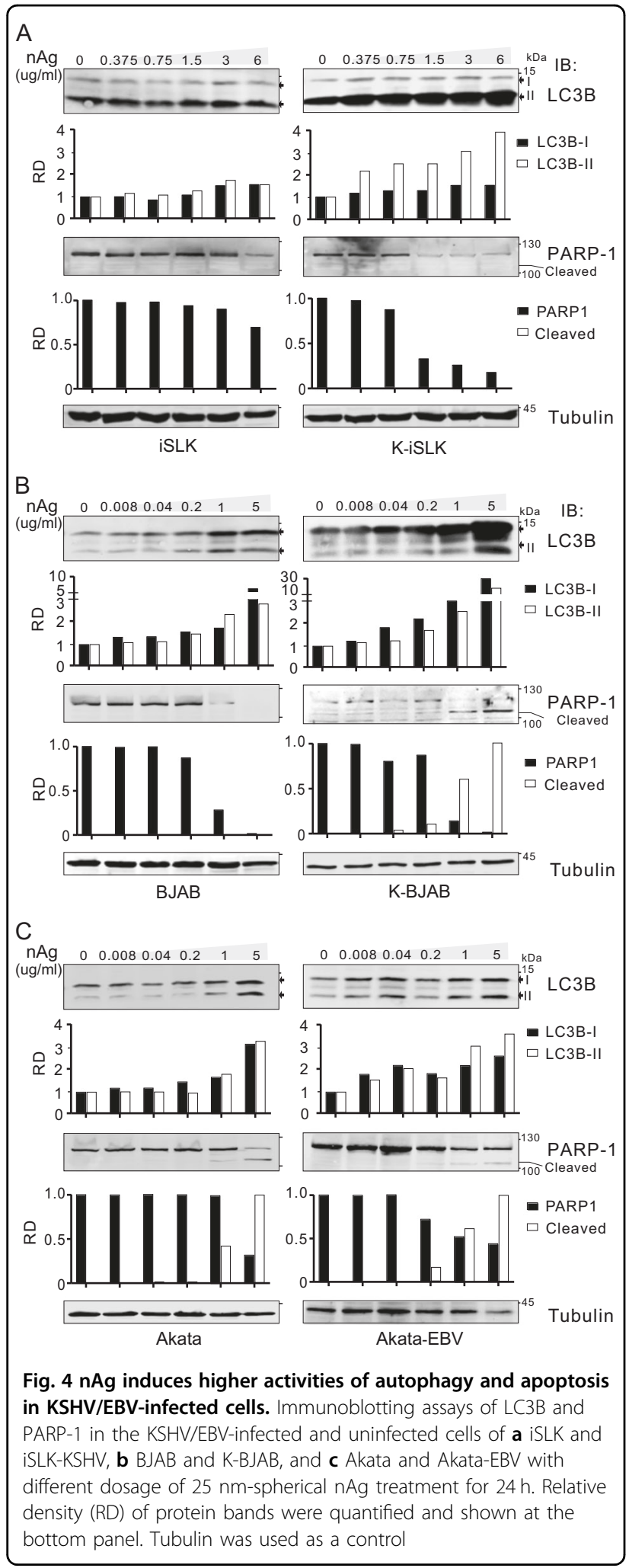

RTA/ZTA were dramatically enhanced by nAg (Fig. 5c), strongly indicating that $\mathrm{nAg}$ reactivates $\mathrm{KSHV} / \mathrm{EBV}$ lytic replication.
Given that $\mathrm{nAg}$ is able to induce cellular ROS production for cytotoxicity ${ }^{27}$. To determine if the life cycle switch induced by $\mathrm{nAg}$ is also relied on ROS generation, the cellular levels of ROS generation in KSHV/EBVlatently infected B-lymphoma cells individually treated with $\mathrm{nAg}$ and NAC (a ROS scavenger) combination or alone were determined by flow cytometry. The results showed that spontaneous and nAg-induced ROS were efficiently inhibited in both the KSHV-infected BCBL1 cells and EBV-infected LCL cells treated with NAC (Fig. 6a). In agreement with this phenomenon, the cytotoxicity and levels of BZLF1/RTA transcripts, as well as virion production caused by $\mathrm{nAg}$ in both BCBL1 and LCL cells were completely released when pretreated with NAC (Fig. 6b), indicating that ROS is indeed involved in the nAg-mediated cytotoxicity and reactivation of $\mathrm{KSHV} /$ EBV lytic replication.

\section{nAg blocks KSHV primary infection by directly destroying virion particles}

To determine if $\mathrm{nAg}$ also has an effect on extracellular $\gamma$-herpesvirus primary infection, HeLa cells were initially pretreated with a series of concentrations of nAg for $48 \mathrm{~h}$ to define the range of cell viability. The results showed that HeLa cells treated with $\mathrm{nAg}$ at $<0.6 \mu \mathrm{g} / \mathrm{ml}$ presented at least $80 \%$ viability (Fig. $7 \mathrm{a}$ ). Therefore, HeLa cells with GFP-tagged KSHV primary infection in the presence or absence of $\mathrm{nAg}$ were analyzed. To exclude the possibility of effect of nAg on the immunofluorescence of GFPtagged KSHV, we have also examined the immunofluorescence intensity of GFP in the iSLK-KSHV cells carrying GFP-tagged KSHV with different dosage of nAg treatment. With the no significant effect of $\mathrm{nAg}$ on the immunofluorescence of GFP-tagged KSHV as parallel control (Fig. 7b), we did not observe significant inhibitory effects on HeLa cells with KSHV primary infection when nAg was replaced with different MOI solution of KSHV virion particles for $24 \mathrm{~h}$ (Fig. 7c). However, remarkable inhibitory effects of $\mathrm{nAg}$ in a dose-dependent manner were observed when $\mathrm{nAg}$ was maintained during infection (Fig. 7d). To elucidate the potential mechanism of the effects of nAg on KSHV primary infection, the binding ability between KSHV virions and host cell, viral entry, and transmission electron microscopy observation of negatively stained KSHV virion particles in the presence or absence of $\mathrm{nAg}$ was individually conducted. The results showed that nAg did not significantly impair the interaction between virion and cell, but reduced the ability of viral entry (Fig. 7e), and caused morphology change of virion particle (KSHV virions alone is a typical spherical shape with an $\sim 100-200 \mathrm{~nm}$ capsid, while they became swollen and flattened after incubation with $0.2 \mu \mathrm{g} / \mathrm{ml} \mathrm{nAg}$ for $2 \mathrm{~h}$ at $37^{\circ} \mathrm{C}$, Fig. 7f). These results indicate that $\mathrm{nAg}$ - 

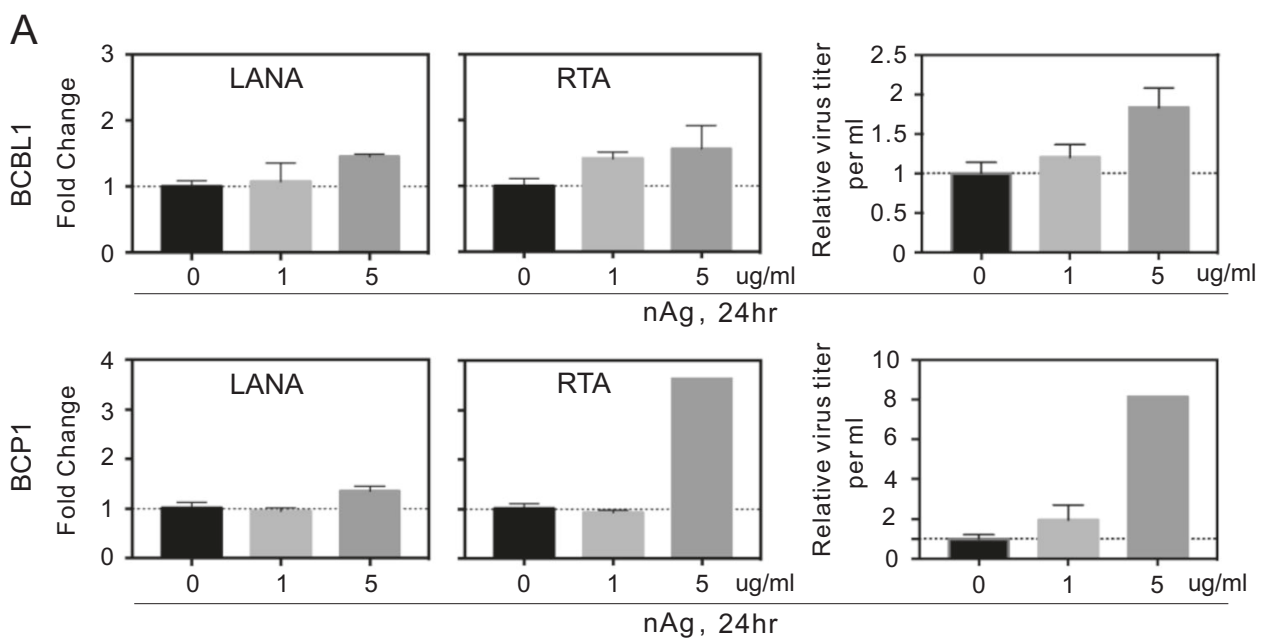

B
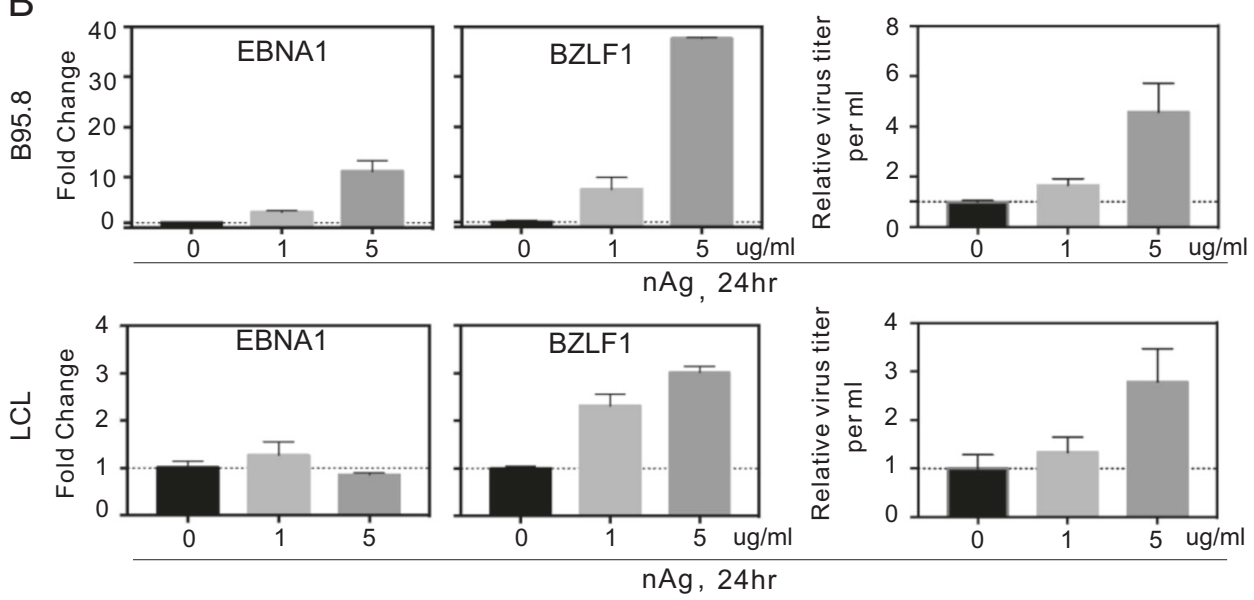

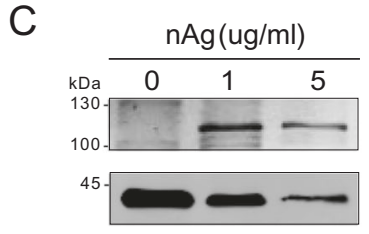

BCBL1

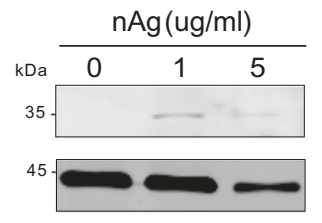

IB:

ZTA

Tubulin

LCL

Fig. $5 \mathrm{nAg}$ activates lytic replication of KSHV/EBV-latently infected cells. Quantitative PCR analysis of a LANA and RTA mRNA transcripts in KSHV-latently infected cells, and $\mathbf{b}$ EBNA1 and BZLF1 mRNA transcripts in EBV-latently infected cells. The viral titers of the supernatant of cells treated with $25 \mathrm{~nm}$-spherical nAg shown in the left panels were individually determined and shown in the right panels. The data presented are the means \pm SD from triplicate analyses. $\mathbf{c}$ Immunoblotting assays of RTA and ZTA (BZLF1) in the BCBL1/LCL cells treated with $25 \mathrm{~nm}$-spherical $\mathrm{nAg}$ from $\mathbf{a}$ and $\mathbf{b}$. Tubulin was used as a control

mediated inhibition of viral infection is likely through direct interaction with virions.

\section{nAg inhibits growth of KSHV-latently infected tumor cells} in vitro and in vivo

The observations above suggested that $\mathrm{nAg}$ can induce stronger cytotoxicity in KSHV/EBV-infected tumor cells and exert antiviral activity against $\mathrm{KSHV} / \mathrm{EBV}$ primary infection. We next investigated whether nAg had the capability to inhibit tumor cell growth and proliferation. To accomplish this, a colony formation assay in vitro and animal experiment were conducted. After an approximately two-week culture period, the number of BCBL1 and LCL colonies was dramatically decreased by $\mathrm{nAg}$ when compared to the untreated control (Fig. 8a), and the inhibitory effects on colony formation of the KSHVinfected tumor cells (iSLK-KSHV and K-BJAB) were greater than those on the KSHV-uninfected tumor cells 

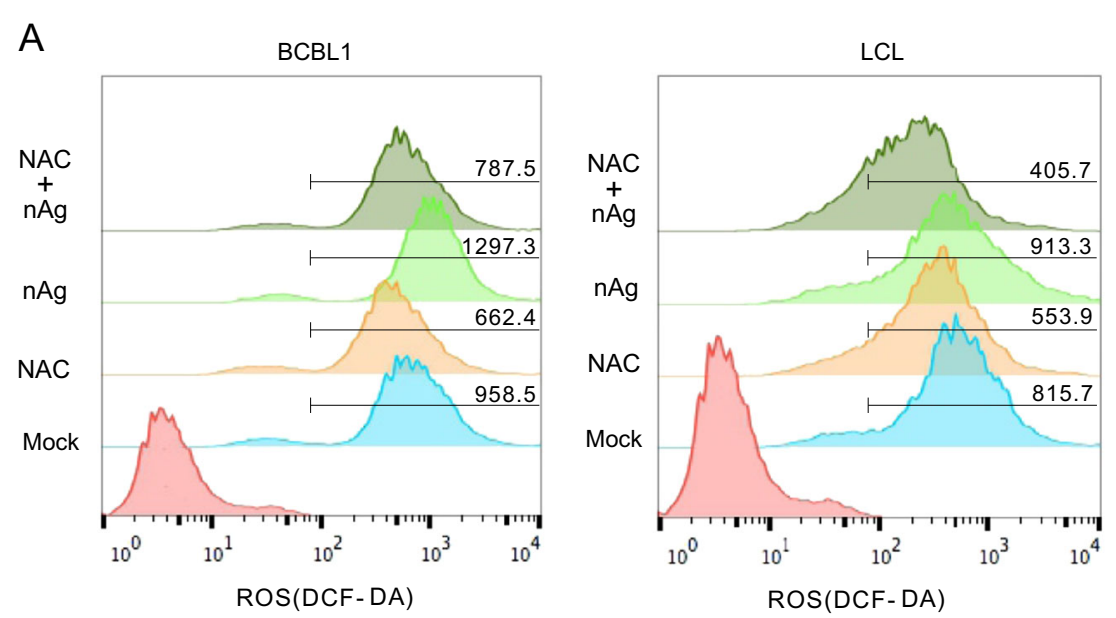

$\mathrm{B}$

Cell Viability

BZLF1/RTA

Viral Titer
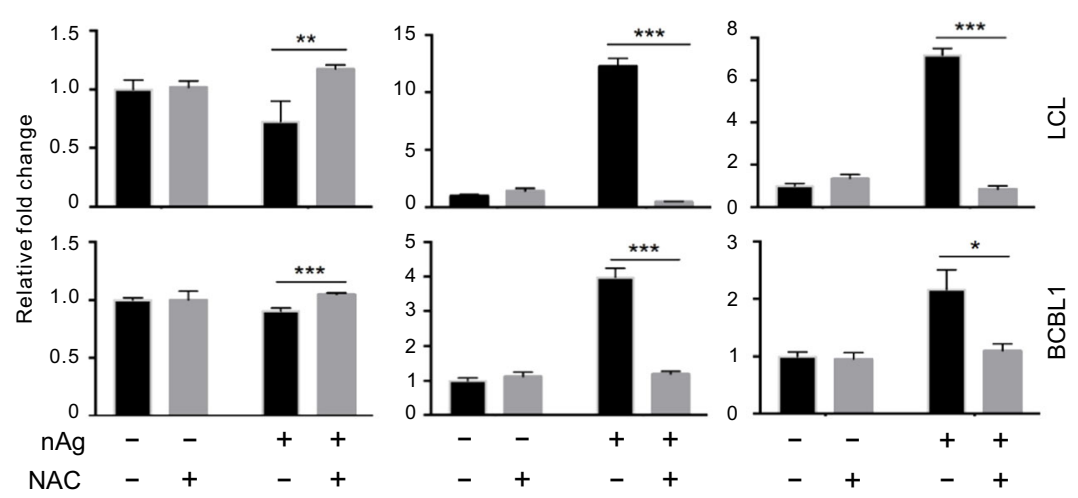

Fig. 6 nAg enhances ROS generation to activate KSHV/EBV lytic replication. a nAg enhances ROS levels in BCBL1/LCL cells. Cells individually treated with NAC, $25 \mathrm{~nm}$-spherical $\mathrm{nAg}(5 \mu \mathrm{g} / \mathrm{ml})$ or their combination for $1 \mathrm{~h}$, were subjected to flow cytometry analysis. $\mathbf{b}$ nAg-induced ROS contributes to the cytotoxicity and lytic replication of KSHV/EBV in BCBL1 and LCL cells. The cells from panel A were subjected to cell viability analysis, quantitative PCR of RTA/BZLF mRNA transcripts and viral titer of the supernatants. The data are presented as the means \pm SD of triplicate analyses. Asterisks indicate $P$ values as follows: ${ }^{*} P<0.05 ;{ }^{*} P<0.01 ;{ }^{* *} P<0.001$

(iSLK and BJAB) (Fig. 8b). To verify the effects of $n A g$ in the xenograft mouse model, the KSHV-associated PEL tumors in NOD/SCID mice were induced by engrafting BCBL1-Luc cells. At week 5 post-engraftment, we performed live bioluminescence imaging and selected 10 mice with higher signals for subsequent experiments. The 10 mice were randomly divided into two groups and treated with PBS or $0.2 \mathrm{mg} \mathrm{nAg}$ per mouse every 3 days for total 3 times. Bioluminescence imaging conducted at day 21 post-treatment showed that all 5 mice in the PBS group had higher luminescent signals, while the luminescent signals in mice 1 and 2 of the treatment group were dramatically reduced to almost undetectable levels, and mice 3, 4 and 5 had relatively higher initial luminescent signals. At day 51 post-treatment, the luminescent signals in mice 1 and 2 of the treatment group increased, while those of other mice remained elevated. Comparison of the average fold change of luminescent signals of mice from the two groups revealed a moderate decrease in fold change for mice treated with $\mathrm{nAg}$ relative to mice treated with PBS (Fig. 8c). These results demonstrated that $\mathrm{nAg}$ had moderate inhibitory effects on tumor development, and the effects were better for mice with smaller tumors.

\section{Discusion}

The oncogenic $\gamma$-herpesviruses KSHV and EBV are causative agents of many human malignancies that are generally resistant to conventional chemotherapy. The occurrence of $\mathrm{KSHV} / \mathrm{EBV}$-associated tumors is closely associated with viral latency, and manipulation of host genes by the viral latent genes usually contributes to the tumorigenesis process. The viruses themselves can serve as potential targets for therapy because almost all tumor cells carry them. Therefore, a common strategy for $\mathrm{KSHV} / \mathrm{EBV}$-associated tumor treatment is to promote 
A

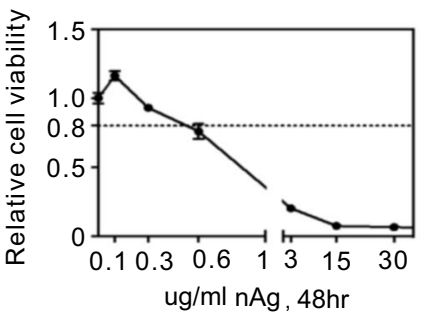

C

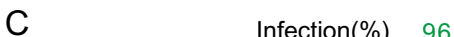

B

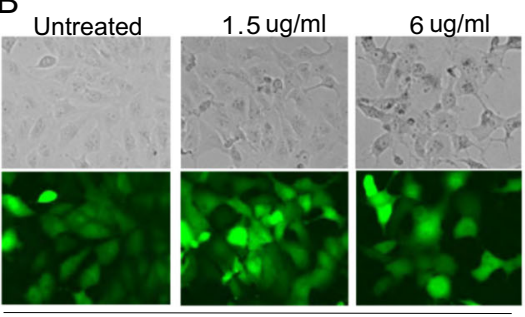

iSLK-KSHV(GFP)

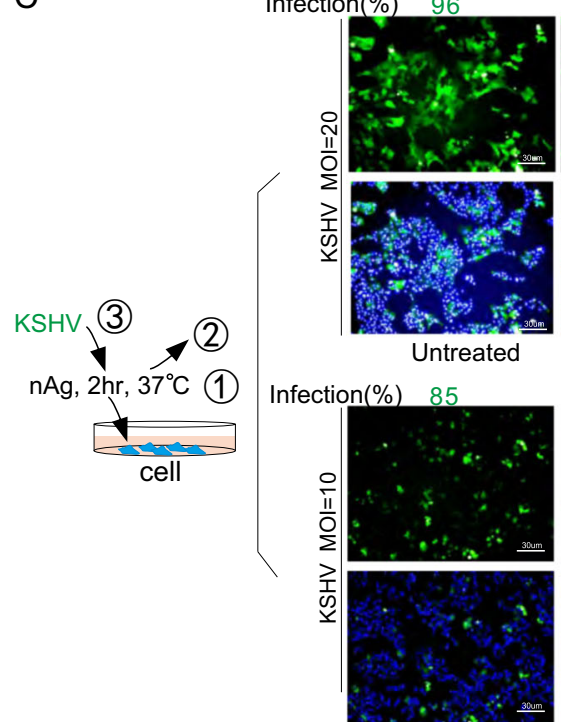

Untreated

95.8

94.8

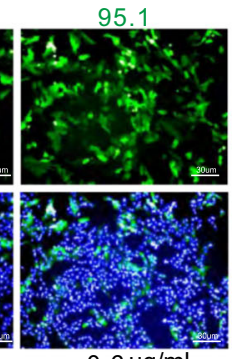

$0.12 \mathrm{ug} / \mathrm{ml}$

$0.6 \mathrm{ug} / \mathrm{m}$
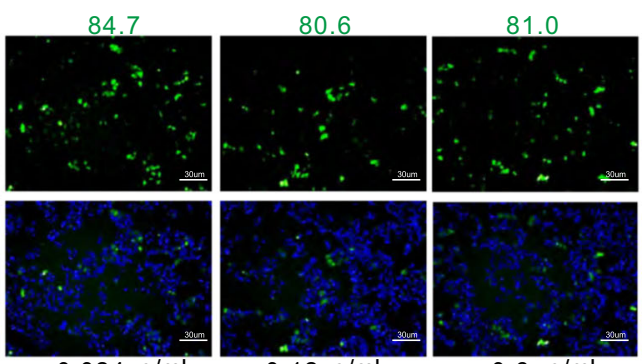

$0.024 \mathrm{ug} / \mathrm{ml}$

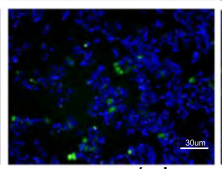

$0.12 \mathrm{ug} / \mathrm{ml}$

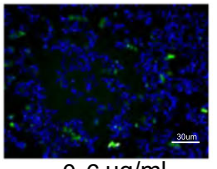

$0.6 \mathrm{ug} / \mathrm{ml}$

D

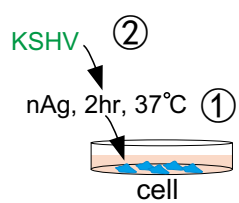

Infection(\%) 86

83.5
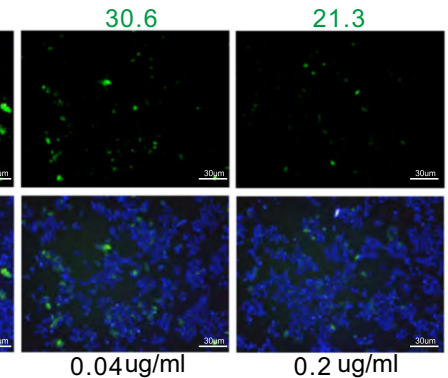

$0.008 \mathrm{ug} / \mathrm{ml}$

$0.04 \mathrm{ug} / \mathrm{ml}$

$0.2 \mathrm{ug} / \mathrm{ml}$

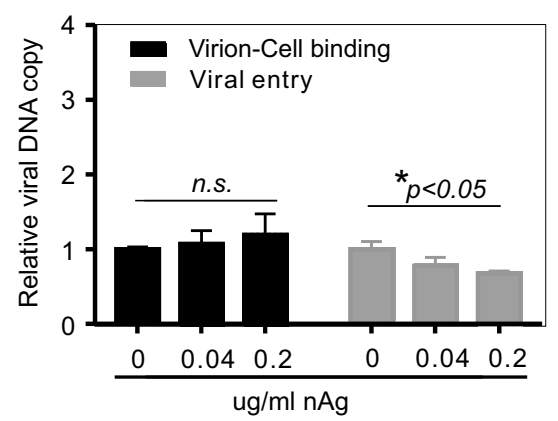

\section{$\mathrm{F}$}

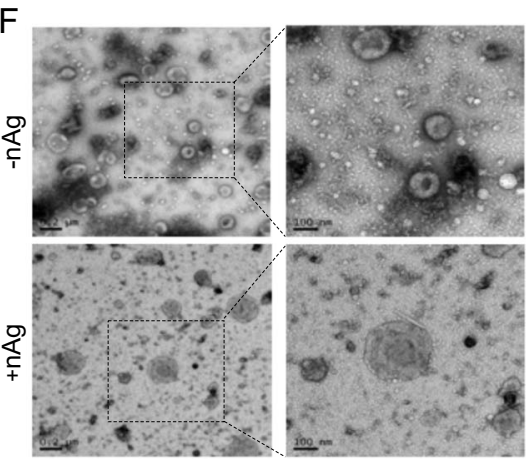

Fig. 7 (See legend on next page.) 
(see figure on previous page)

Fig. $7 \mathrm{nAg}$ inhibits KSHV primary infection via destruction of the virion particle. a Relative viability of HeLa cells treated with different concentrations of $25 \mathrm{~nm}$-spherical nAg for $48 \mathrm{~h}$. $\mathbf{b}$ nAg does not impair the immunofluorescence of GFP-tagged KSHV. Immunofluorescence assays of iSLK cells carrying GFP-tagged KSHV (iSLK-KSHV) treated with different dosage of $25 \mathrm{~nm}$-spherical nAg for $48 \mathrm{~h}$. Cell morphology analyzed by light microscopy was used as control. c The efficiency of HeLa cells with KSHV infection in the absence of nAg. Cells were incubated with different concentrations of $25 \mathrm{~nm}$-spherical nAg for $2 \mathrm{~h}$ and then discarded before GFP-KSHV virion (generated from iSLK-KSHV cells) infection (MOI = 10, 20). A schematic diagram of the infection protocol is shown on the left panels. At $48 \mathrm{~h}$ post-infection, the infection percentage was quantified and shown on the top panels. $\mathbf{d}$ The infection efficiency of HeLa cells infected with KSHV virions $(\mathrm{MOI}=15)$ in the presence of $25 \mathrm{~nm}$-spherical nAg. A schematic diagram of the infection protocol is shown on the left panels. At $48 \mathrm{~h}$ post-infection, the infection percentage was quantified and shown on the top panels. e nAg does not impair virion-cell attachment but increase viral entry. HeLa cells incubated with KSHV virions in the presence or absence of $\mathrm{nAg}$ as indicated in panel $\mathrm{D}$, were subjected to virion-cell attachment and viral entry analysis by quantitative PCR. Asterisk indicates $p<0.05$. n.S., no significant. $\mathbf{f}$ Representative photograph of KSHV virion particle in the presence or absence of nAg under TEM. KSHV virions were incubated with or without $0.2 \mathrm{\mu g} / \mathrm{ml} 25 \mathrm{~nm}$-spherical nAg for $2 \mathrm{~h}$ at $37^{\circ} \mathrm{C}$. Scale bars are 200 and $100 \mathrm{~nm}$ as indicated in the figure. Enlarged magnification is shown on the right panel

virus entry into lytic replication from latency. When this occurs, the quiescent condition is broken, after which a large number of lytic genes are expressed following virion packaging and release, leading to death of the tumor cell. However, virions released during lytic replication may lead to new infection and increase the long-term risk associated with tumors. In this study, we found for the first time that $\mathrm{nAg}$ presented exclusively higher cytotoxicity on KSHV/EBV-latently infected cells through reactivating viral lytic replication, and that this also blocks KSHV primary infection by directly destroying virion particles (Fig. 9). These findings indicate that nAg could be a promising therapeutic agent for treatment of KSHV/ EBV-associated tumors by targeting latent and lytic replication of the life cycle. In agreement with previous findings about the effect of $\mathrm{nAg}^{26}$, activation of autophagy and apoptosis were observed in KSHV/EBV-latently infected cells that received $\mathrm{nAg}$ treatment.

$\mathrm{nAg}$ toxicity usually depends on properties such as size, shape and surface coating ${ }^{28}$. Smaller sized $\mathrm{nAg}$ are taken up into cells in greater abundance through endocytosis, leading to greater toxicity ${ }^{9,29}$, while larger $\mathrm{nAg}$ are not internalized $^{30,31}$. Consistent with previous reports ${ }^{24,28}$, we observed that the shape of $\mathrm{nAg}$ also influences their cytotoxicity toward epithelial and B-lymphoma cells, with smaller spherical $\mathrm{nAg}$ having higher toxicity than larger spherical nAg.

It has been demonstrated that viral lytic replication can be induced by a variety of extracellular stresses, such as cytokine signaling, cell differentiation, co-infection, hypoxia $^{20,32}$. nAg not only induces KSHV/EBV-latently infected tumor cell cytotoxicity in a dose-dependent and time-dependent manner, it also has greater toxicity toward KSHV/EBV-infected cells than toward uninfected tumor cells. Our studies revealed that nAg-induced cytotoxicity and lytic replication can be blocked when pretreated with the effective ROS scavenger NAC, suggesting that ROS is involved in nAg-mediated lytic reactivation and fundamental cytotoxicity, and that $\mathrm{nAg}$ is another stimuli to reactivate lytic replication from latency.
Based on the finding that $\mathrm{nAg}$ presents specific greater cytotoxicity toward tumor cells harboring $\mathrm{KSHV} / \mathrm{EBV}$, we could adjust the treatment concentration and time of $\mathrm{nAg}$ to efficiently control the development of KSHV/EBVassociated tumors. More importantly, we found that nAg could directly destroy the KSHV virion particles and block viral primary infection, even at concentrations that are not cytotoxic. Despite previous studies have shown that $\mathrm{nAg}$ can preferentially bind with the gp120 subunit of viral envelope glycoprotein to block HIV-1 CD4-dependent virion entry ${ }^{3}$, the entry of $\gamma$-herpesvirus into host cells relies on several corresponding cellular receptors ${ }^{33,34}$, the specific cellular receptor or corresponding viral glycoprotein interaction with $\mathrm{nAg}$ for blocking KSHV primary infection requires further investigation. In addition, although the treatment of $\mathrm{nAg}$ did not dramatically impair the interaction of viron and cell, the finding of increase of viral entry indicate that $\mathrm{nAg}$ treatment may enhance the efficiency of viral entry of permissive cell surfaces, and then influence KSHV primary infection for latent-infection establishment at long-term time point.

During treatment of $\gamma$-herpesvirus associated diseases, it is often ignored the fact that co-infection is a common phenomenon for $\gamma$-herpesvirus. For instance, populations affected by KSHV are usually composed of individuals with immunodeficiency, such as AIDS patients ${ }^{35}$. EBV, which occurs as an asymptomatic life-long infection in $\sim 95 \%$ of the world's population, can also co-infect with $\mathrm{HIV}$ and several other viruses, such as HCV and hCMV ${ }^{36}$. Our studies provide evidence that $\mathrm{nAg}$ has also an antiviral activity against KSHV and EBV, which added up broad-spectrum antiviral activities against co-infection of both KSHV/EBV and different viruses including drugresistant strain HIV. Therefore, nAg has greater advantages than conventional drugs because it has a broadspectrum and does not induce drug-tolerance.

In addition, in view of the inhibitory effect of $\mathrm{nAg}$ on $\mathrm{KSHV} / \mathrm{EBV}$-associated tumors, although it exerts significant inhibitory effects on the colony formation of KSHV/EBV-infected cells in vitro, only a moderate 
A

B

C
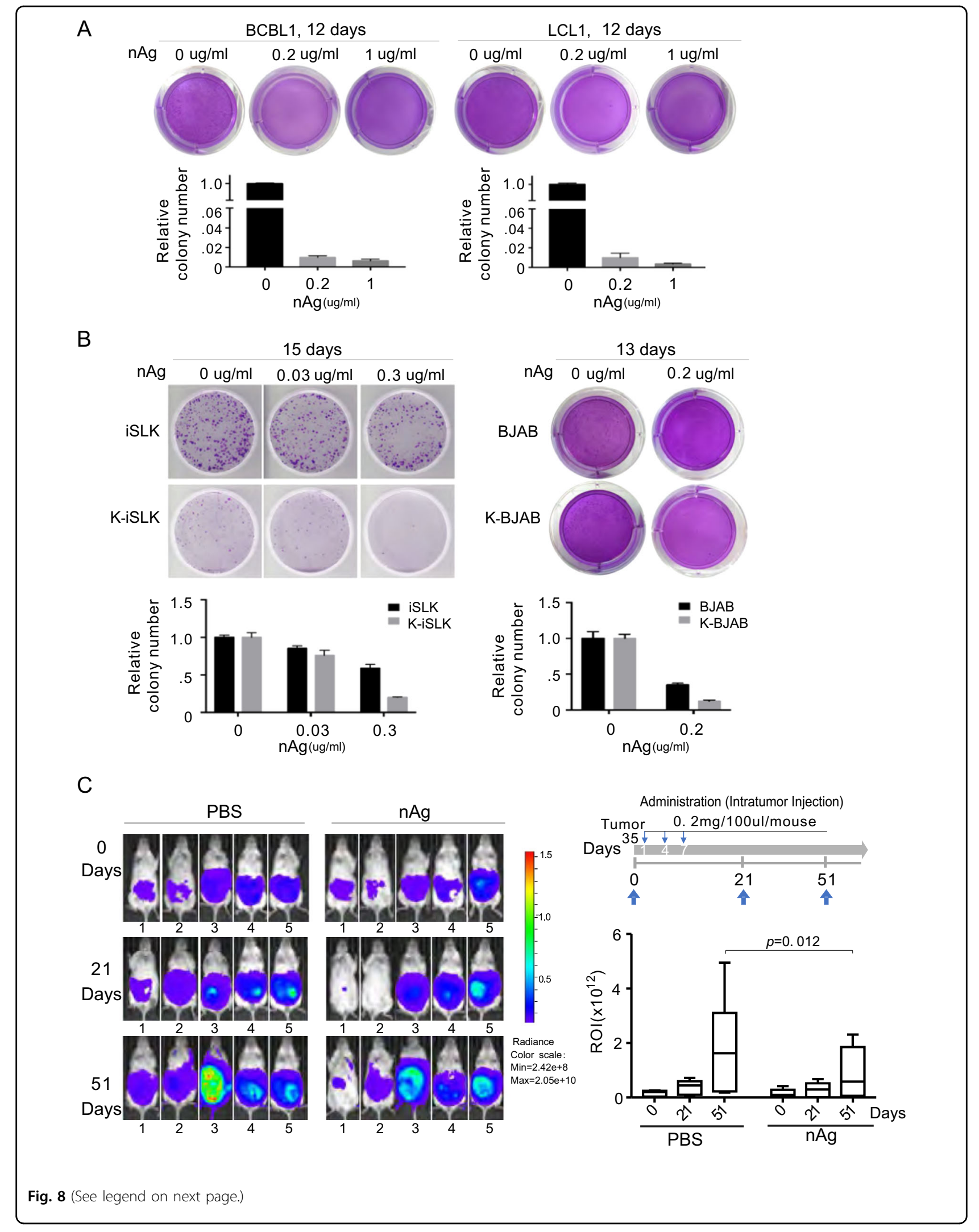
(see figure on previous page)

Fig. $8 \mathrm{nAg}$ exerts moderate inhibitory effects on KSHV-associated tumor growth. a nAg dramatically reduces colony formation of KSHV/EBVinfected cells. BCBL-1 and LCL cells were treated with different concentrations of $25 \mathrm{~nm}$-spherical $\mathrm{nAg}$ and subjected to colony formation assays for 12 days. Bottom panel, the relative colony number was calculated from two independent experiments. $\mathbf{b} \mathrm{nAg}$ preferentially reduces colony formation of KSHV-infected cells in vitro. KSHV-infected and uninfected iSLK and BJAB cells treated with different concentrations of $25 \mathrm{~nm}$-spherical nAg were subjected to colony formation assays for 15 and 13 days. Bottom panel, the relative colony number was calculated from two independent experiments. c nAg moderately inhibits growth of KSHV-infected PEL in vivo. The tumor burdens of NOD/SCID mice were analyzed by luminescence assay at day 0, 21 and 51 following treatment with $25 \mathrm{~nm}$-spherical nAg every two days for three times (top panel). Luminescent signals from the left panel were quantified and expressed based on region-of-interest (ROI) signal intensity (right panel). The average of luminescent signals of each group from the two experiments is shown

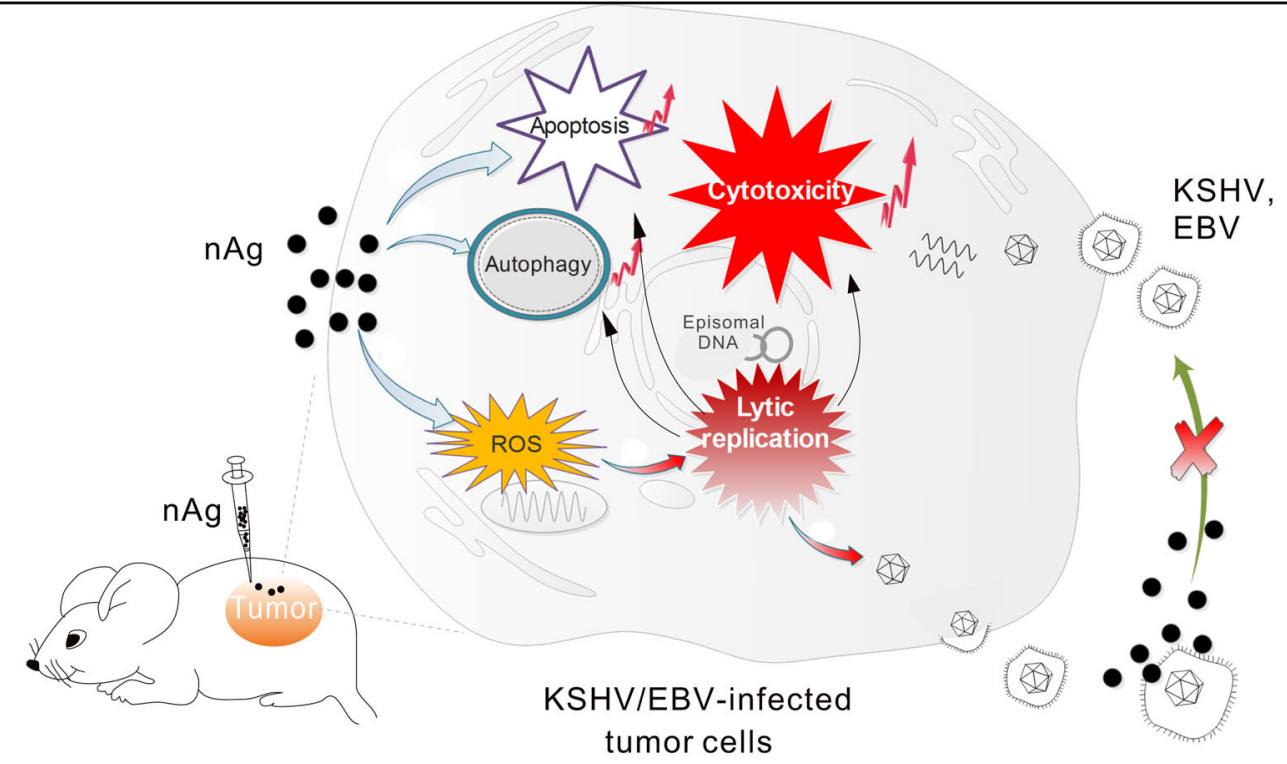

Tumor Cell Death

Fig. 9 Proposed model of $\mathbf{n A g}$-mediated inhibitory effects on $\boldsymbol{\gamma}$-herpesvirus-associated tumor cells. nAg exhibits stronger cytotoxicity in the Y-herpesvirus-infected tumor cells through inducing viral lytic reactivation, which relies on ROS generation. Moreover, nAg can block further primary infection by directly destroying virion particles

inhibition of tumor growth was observed in vivo in a xenograft mouse model. This could be due to only small amounts of total $\mathrm{nAg}$ are accumulated in the target tissues after injection into body. To avoid this problem, nAg can be linked with specific polypeptides targeting tumor cells or cellular receptors of virus entry to increase the efficiency of specific targeting for tumor cells or viruses. Based on advanced nanotechnology, we believe next generation of nAg can be refined to impart it with addition functions.

\section{Materials and methods Characterization of $\mathrm{nAg}$}

Silver nanoparticles (nAg) with different size and shape, which generated by using liquid-chemical synthesis technology and polyvinylpyrrolidone (PVP) as a coating buffer, were purchased from Shanghai Huzheng
Nanotechnology Co. Ltd., CN, or nanoComposix, Inc., USA. Stock nAg solutions were stored at $4{ }^{\circ} \mathrm{C}$ in the dark.

\section{Ethics statement and husbandry}

Healthy human blood was obtained from Shanghai Skin Disease Hospital. Usage of blood samples for research purposes was approved by the Hospital Medical Ethics Committee. All of the animal studies were conducted in accordance with the Chinese Guide for the Care and Use of Laboratory Animals. All of the experiments were approved and overseen by the institutional animal care and use committee of Fudan University under Protocol ID 196086. Mice were housed in microisolator cages with no more than 5 mice per cage in certified specific-pathogenfree or germ-free vivaria. Animals were provided with access to autoclaved water and food ad libitum. 


\section{Reagents and antibodies}

Antibodies to PARP1 (F2, Santa cruz), Caspase-3 (H-277, Santa cruz), EBV ZEBRA (sc-53904, Santa cruz), LC3B (GT3612, GeneTex), SQSTM1 (ab56416, Abcam) and Tubulin (66031-1, Proteintech) were used according to the manufacturers specifications. Mouse monoclonal antibodies against RTA were kindly provided by Ke Lan from Wuhan University. Tetradecanoyl Phorbol Acetate (TPA) was purchased from Sigma and sodium butyrate from J\&K Corporation. 3-Methyladenine (3-MA), and Choloquine (Chl) were purchased from Sigma-Aldrich. Doxycycline (DOX) was purchased from Sangon Biotech (Shanghai).

\section{Cells cultures}

The EBV and KSHV negative (HEK 293T, iSLK, HeLa, $\mathrm{BJAB}$, and Akata), KSHV-positive (iSLK-KSHV, K-HeLa, $\mathrm{K}-\mathrm{BJAB}, \mathrm{BCBL}-1$, and BCP1), and EBV-positive (AkataEBV, B95.8, LCL) cell lines were used. Human peripheral blood mononuclear cells (PBMCs) were used as primary cell lines. Both iSLK and iSLK-KSHV cells were gifts from Shou-Jiang Gao at the University of South California, PBMC were isolated from healthy human blood (from Shanghai Skin Disease Hospital), and other cell lines were from the American Type Culture Collection (ATCC). Adherent cells and suspension cells were maintained in Dulbecco's modified Eagle's medium (DMEM) and Roswell Park Memorial Institute (RPMI 1640) medium, respectively, containing $10 \%$ fetal bovine serum (FBS) and $1 \%$ penicillin and streptomycin. iSLK were grown in the

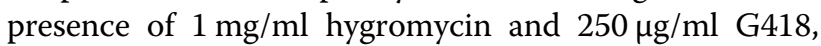
while iSLK-Bac16 grew in the presence of $1 \mathrm{mg} / \mathrm{ml}$ hygromycin, $250 \mu \mathrm{g} / \mathrm{ml} \mathrm{G} 418$, and $1 \mu \mathrm{g} / \mathrm{ml}$ puromycin. All of the cell lines were incubated at $37^{\circ} \mathrm{C}$ in a $5 \% \mathrm{CO}_{2}$ incubator, during which time they were passaged once every 2 to 3 days. DMEM, RPMI-1640, FBS and Trypsin were purchased from Gibco (USA).

\section{Cytotoxicity assay}

The cytotoxicity of nAg treatments towards adherent cells was determined by methyl thiazolyl tetrazolium (MTT, Sigma-Aldrich, St. Louis, MO) assay. The adherent cells were seeded into a 96-well plate at a density of $7 \times$ $10^{3} / 100 \mu \mathrm{l}$ and held at $37^{\circ} \mathrm{C}$ in a $5 \% \mathrm{CO}_{2}$ incubator overnight, after which the media was replaced with $100 \mu \mathrm{l}$ medium containing $\mathrm{nAg}$ (five replicates) and further incubated for $24 \mathrm{~h}$ and $48 \mathrm{~h}$. Following treatment, MTT solution was added and incubated for $4 \mathrm{~h}$ at $37^{\circ} \mathrm{C}$. After discarding the medium, $150 \mu \mathrm{l}$ MTT Solvent $[4 \mathrm{mM}$ $\mathrm{HCl}, 0.1 \%$ Nondet P-40 (NP40) in isopropanol] was added for solubilization and the absorbance value was measured. The cytotoxicity of nAg treatments towards cell suspensions was determined by trypan blue (SigmaAldrich, St. Louis, MO, USA) assay. The cell suspensions were incubated with $\mathrm{nAg}$ at various dilutions (five replicates) for $24 \mathrm{~h}$ and $48 \mathrm{~h}$. The amount and proportion of living cells were determined using cell viability image analyzer Vi-CELL XR (Beckman Coulter, Indianapolis, IN, USA) and the results were normalized against the viability of the control. The 50\% cytotoxic concentration (CC50) was calculated from the following equation: $\log$ (inhibitor) vs response curve, which was given by $\mathrm{Y}=$ bottom + (top - bottom $) /(1+10(\log$ IC50-X $) \times$ slope $)$ using the GraphPad Prism 7 program.

The morphology of cells incubated with nAg was visualized using a standard microscope or a Leica SP8 confocal microscope after TRITC phalloidin (YEASEN \#40734ES75, CN) staining according to the manufacturer's instructions. Nuclei were counterstained with 4, 6-diamidino-2-phenylindole (DAPI). Briefly, cells that were treated with nAg were washed with PBS twice, then fixed in $4 \%$ paraformaldehyde for $20 \mathrm{~min}$, after which cell suspensions were allowed to attach to the plate. The cells fixed on the plate were permeabilized in PBS containing $0.2 \%$ fish skin gelatin and $0.2 \%$ Triton X-100 for $5 \mathrm{~min}$, then incubated with $100 \mathrm{nM}$ TRITC Phalloidin for $30 \mathrm{~min}$ at room temperature.

\section{Apoptosis analysis}

Intracellular apoptosis levels were detected by Annexin$\mathrm{V}$ and propidium iodide (PI) staining using an Annexin V FITC Apoptosis Kit (BD \#556547, USA), according to the manufacturer's instructions with a flow cytometry. Briefly, $1 \times 10^{6}$ BCBL1 cells were collected and washed with cold PBS twice after treatment with $\mathrm{nAg}$ for $48 \mathrm{~h}$, then suspended with $100 \mu$ l binding buffer, and incubated with Annexin V FITC and PI at room temperature for $15 \mathrm{~min}$. Cellular apoptosis level was measured with a FACScan flow cytometer and analyzed with the FlowJo software. For each sample 10,000 events were collected.

\section{Detection of Intracellular ROS}

Intracellular ROS levels were measured using an oxidation-sensitive fluorescent probe (DCFH-DA) through flow cytometry according to the manufacturer's instructions of Reactive Oxygen Species Assay Kit (Beyotime Co., CN). Briefly, $1 \times 10^{6}$ cells were collected and washed with PBS twice after treatment with $\mathrm{nAg}$ for $2 \mathrm{~h}$ in the presence or absence of $10 \mathrm{mM} \mathrm{N}$-acetyl-Lcysteine (NAC, Beyotime Co., CN) for $1 \mathrm{~h}$, then incubated with $10 \mu \mathrm{M}$ DCFH-DH at $37^{\circ} \mathrm{C}$ for $20 \mathrm{~min}$. Specifically, DCFH-DA was deacetylated into DCFH using intracellular nonspecific esterase, then further oxidized by intracellular ROS into DCF with fluorescence, which was detected using a FACScan flow cytometer (BD Biosciences, Foster, CA, USA) and analyzed with the FlowJo software. For each sample 10,000 events were collected. 


\section{Quantitative PCR}

Total RNA was extracted by using TRIzol reagent (Invitrogen, US) according to manufacturer's instruction, and reverse transcribed into cDNA with Superscript II reverse transcription kit (YEASEN, CN). The cDNA was amplified in a $20 \mu \mathrm{l}$ total volume containing $10 \mu \mathrm{l}$ SYBR green, $0.4 \mu \mathrm{l}$ each primer $(10 \mu \mathrm{M}), 4.2 \mathrm{ul} \mathrm{H}_{2} \mathrm{O}$, and $5 \mu \mathrm{l}$ cDNA. A melting-curve analysis was performed to verify the specificities of the amplified products. The values for the relative levels of change were calculated by the threshold cycle $(\Delta \Delta \mathrm{CT})$ method, and samples were tested in triplicates. The primers targeting KSHV ORF73 (sense: 5'-GGGGTACACACTACGGTTGG-3', anti-sense: 5'-T CCCGCAACACCT TTACCTC-3', 429 bps), KSHV OR F50 (sense: 5'-GATGTCGGGTCGCCTCTCTC-3', antisense: 5'-GTGCCGGACTCCTGTACCTC-3', 228 bps), EBV EBNA1 (sense: 5'-CTGGAAATGGCCTAGGAGA G-3'; anti-sense: 5'-TATGTCTTGGCCCTGATCCT-3', $171 \mathrm{bps}$ ), and EBV BZLF1 (sense: 5'-TGATTCTGGGTTATGTCGGA-3'; anti-sense: 5'-AGGCCAGCTAACTG CCTATC-3', 137 bps), respectively. The ORF72 (sense: 5'-TATTTGGGACCTTTCAACAATCTCTT-3'; anti-sen se: 5' - GTTCCACTGCCGCCTGTA-3', 609 bps) or EBN A1 (sense: 5' - CAATGGTGTAAGACGACATT -3'; antisense: 5'- CCTGTAGGGGAAGCCGAT -3', 387 bps) were used for quantitation of KSHV and EBV viral titer, respectively. Actin (sense: 5'-GGCATCCACGAAACTAC CTT-3'; anti-sense: 5'- TGATCTCCTTCTGCATCCTG $-3^{\prime}, 136 \mathrm{bps}$ ) was used as an internal control.

\section{Protein Extraction and Immunoblotting}

The harvested cells were washed twice with cold PBS, then lysed in $500 \mu$ l RIPA buffer [ $150 \mathrm{mM} \mathrm{NaCl}, 50 \mathrm{mM}$ Tris (pH 7.6), 1\% Nonidet P-40, 2 mM EDTA, proteinase inhibitor mixture (1 mM phenmethyl sulfonyl fluorine, $1 \mathrm{~g} / \mathrm{ml}$ aprotinin, $1 \mathrm{~g} / \mathrm{ml}$ leupeptin, and $1 \mathrm{~g} / \mathrm{ml}$ pepstatin)] for $30 \mathrm{~min}$ with constant oscillation at $4{ }^{\circ} \mathrm{C}$. After centrifugation at $14,500 \mathrm{rpm}, 4^{\circ} \mathrm{C}$ for $5 \mathrm{~min}$, cell debris was removed. The supernatant was then transferred to a new eppendorf tube, after which the protein samples were boiled in 6x DTT loading buffer according to the concentration of protein that was determined by the Bradford method. Next, the samples were separated by SDS-PAGE and then transferred to a $0.45-\mathrm{mm}$ nitrocellulose filter. After blocking, the protein in the membrane was probed with primary antibodies at $4{ }^{\circ} \mathrm{C}$ overnight, and then incubated with appropriate secondary antibodies for another $1 \mathrm{~h}$ at room temperature. Finally, the membrane was visualized using an Odyssey Infrared scanner (Li-Cor Biosciences, US) for optical density analysis.

\section{Extraction and quantitation of virion production}

The supernatant of KSHV/EBV-positive cell lines treated with nAg was harvested and digested with DNase at $37^{\circ} \mathrm{C}$ for $30 \mathrm{~min}$ to remove cellular DNA debris, after which the reaction was terminated by treatment with $5 \mathrm{mM}$ EDTA at $75^{\circ} \mathrm{C}$ for $10 \mathrm{~min}$. Samples were then resuspended in HMW buffer, $0.5 \%$ SDS and $100 \mu \mathrm{g} / \mathrm{ml}$ proteinase $\mathrm{K}$ at $60^{\circ} \mathrm{C}$ for $2 \mathrm{~h}$. Next, an equal volume of phenol and chloroform (1:1) was added, after which the samples were centrifuged at $12,000 \mathrm{rpm}, 4^{\circ} \mathrm{C}$ for $5 \mathrm{~min}$. Episomal DNA in the supernatant was subsequently precipitated by adding $3 \mathrm{M}$ sodium acetate $(1 / 10, \mathrm{v} / \mathrm{v})$ and twice the volume of $100 \%$ alcohol, then stored at $-80{ }^{\circ} \mathrm{C}$ for $30 \mathrm{~min}$, after which samples were centrifuged at $12,000 \mathrm{rpm}, 4^{\circ} \mathrm{C}$ for $10 \mathrm{~min}$. Finally, the DNA was washed, dried in the air, dissolved in deionized water, and used for virion quantification by $\mathrm{qPCR}$.

\section{KSHV Virion Purification and Primary Infection}

iSLK-KSHV cells carrying GFP-tagged KSHV genome as described previously ${ }^{37}$, were induced with $1 \mu \mathrm{g} / \mathrm{ml}$ of Dox and $1 \mathrm{mM}$ sodium butyrate $(\mathrm{NaB})$ for 5 days at $37^{\circ} \mathrm{C}$ under $5 \% \mathrm{CO}_{2}$. Following induction, the supernatant of the culture medium was filtered through a $0.45 \mu \mathrm{m}$ filter on ice, after which the viral particles were spun down at $25,000 \mathrm{rpm}$ for $2 \mathrm{~h}$ at $4{ }^{\circ} \mathrm{C}$. Finally, the concentrated viruses were then collected and re-suspended in RPMI 1640 medium, and stored at $-80^{\circ} \mathrm{C}$ until used for virion quantification by qPCR.

HeLa cells were seeded into 96-well plates at a density of $1 \times 10^{4}$ cells per well containing $100 \mu \mathrm{l}$ media overnight to adhere, then exposed to nAg at different final concentrations and further incubated for $2 \mathrm{~h}$ at $37^{\circ} \mathrm{C}$. The media containing $\mathrm{nAg}$ was discarded or maintained during infection. After which KSHV extracted from iSLKKSHV cells was added at a MOI (multiplicity of infection) of 10 to 20 , then spin infected $\left(1500 \mathrm{~g}, 25^{\circ} \mathrm{C}\right)$ for $1 \mathrm{~h}$ and finally incubated at $37^{\circ} \mathrm{C}$ for $48 \mathrm{~h}$. KSHV de novo infection of HeLa cells was performed through spin infection and the infection efficiency was determined by counting the percentage of GFP-positive cells after infection.

\section{Virion-cell binding and viral entry assay}

To determine virion-cell attachment, $1 \times 10^{5} \mathrm{HeLa}$ cells that treated with different dosage of $\mathrm{nAg}(0,0.04,0.2 \mu \mathrm{g} /$ $\mathrm{ml}$ ) at $37^{\circ} \mathrm{C}$ for $2 \mathrm{~h}$ were incubated with KSHV on ice for $1 \mathrm{~h}$. Then cells were washed twice with PBS to remove unbound virus and lysed immediately by DNA extraction. For viral entry, HeLa cells that incubated with KSHV on ice for $1 \mathrm{~h}$, were followed by incubation for another $1 \mathrm{~h}$ at $37^{\circ} \mathrm{C}$. Then cells were digested with $0.05 \%$ trypsin-EDTA at $37^{\circ} \mathrm{C}$ for $5 \mathrm{~min}$ to remove noninternalized virus. Finally, the cells were washed twice with PBS and lysed immediately by DNA extraction. For both viral-cell binding and entry assays, KSHV DNA copies in cells were quantitated by qPCR using ORF73 as target. 


\section{Transmission Electron Microscopy (TEM)}

KSHV virion (concentration was $2 \times 10^{8} / \mathrm{ml}, 20 \mu \mathrm{l}$ ) was mixed with or without $\mathrm{nAg}$ at final concentration of $0.2 \mu \mathrm{g} /$ $\mathrm{ml}$ and maintained at $37^{\circ} \mathrm{C}$ for $2 \mathrm{~h}$. A copper mesh with carbon support film was placed over the sample droplets (50 $\mu \mathrm{l}$ sample containing $10^{7} / \mathrm{ml}$ of virus particles) and allowed to float for $3-10 \mathrm{~min}$ to ensure that the virus particles could adsorb onto the support film. The copper mesh was then removed from the sample droplets and placed on filter paper for liquid absorption, followed by staining on the $2 \%$ phosphotungstic acid-dyed droplets, and floating for $3 \mathrm{~min}$. After absorbing the liquid, the copper mesh was dried under an incandescent lamp for $10 \mathrm{~min}$ and then observed under a FEI Tecnai G2 Spirit transmission electron microscopy (Thermo Fisher Scientific, USA).

\section{Colony formation assay}

Adherent cells were cultured in $10 \mathrm{~cm}$ dishes $(3000$ cells/plate) for $24 \mathrm{~h}$ to adhere, after which culture was continued in the presence of nAg for 15 days. Next, the medium was removed, and cells were washed twice with PBS, fixed with $4 \%$ formaldehyde and stained with $0.1 \%$ crystal violet. Colony formation in each dish was scanned using a Li-Cor Odyssey image system.

Soft-agar colony formation assay was used to generate cell suspensions. Briefly, two soft agar layers were placed into 6-well plates. The base agar layer consisted of $2 \mathrm{ml}$ DMEM containing $10 \%$ FBS and $0.75 \%$ agar that was melted in a microwave and then kept at $56{ }^{\circ} \mathrm{C}$, while the top agar layer consisted of $2 \times 10^{4}$ cells in $2 \mathrm{ml}$ DMEM containing $10 \%$ FBS, $0.36 \%$ agar and $\mathrm{nAg}$ at different final concentrations. After about 2 weeks, cells were stained with $0.04 \%$ crystal violet and $2 \%$ ethyl alcohol and colony formation in each dish was photographed.

\section{Animal experiments}

Five-week-old female NOD/SCID mice (purchased from Beijing Vital River Laboratory Animal Technology Co., Ltd., Beijing, $\mathrm{CN}$ ) were injected intraperitoneally with $200 \mu \mathrm{l}$ of PBS containing $10 \times 10^{6}$ BCBL1-Luc cells. The mice were then subjected to live imaging at 5 weeks postinoculation. Briefly, mice were injected with D-luciferin at $150 \mathrm{mg} / \mathrm{kg}$ body weight twelve minutes later, the mice were imaged for $0.1 \mathrm{~s}, 0.5 \mathrm{~s}$ using an IVIS Spectrum Imaging System (PerkinElmer, USA). Ten successfully established model mice were randomly divided into two groups, a treatment group that received intraperitoneal injection of $100 \mu \mathrm{lnAg}$ at $2 \mathrm{mg} / \mathrm{ml}$ every two days until three injections had been administered, and a control that received intraperitoneal injections of PBS under the same conditions. At day 21 and 51 post-treatment, tumor development in the model mice was observed via live images and the results were presented as total radiance within the ROI after mice were imaged for $0.5 \mathrm{~s}$.

\section{Statistical analysis}

Statistical parameters including the definition and exact values of $n$, distribution and deviation are reported in the figure legends. Data are expressed as mean \pm standard deviation (SD). The significance of the variability between two groups was determined by one-way analyses of variance using GraphPad Prism 7 software (GraphPad Software, Inc, La Jolla, CA, USA). A $p$ value of $<0.05$ was considered statistically significant and a $p$ value of $>0.05$ was considered statistically non-significant.

\begin{abstract}
Acknowledgements
We are grateful to Shou-Jiang Gao from University of Pittsburgh and Erle Robertson from University of Pennsylvania for providing reagents. This work was supported by the National Natural Science Foundation of China (81672015, 81471930 to Q.C.; 81772166 to F.W., 81572054 to Y.G., 81501739 to C.Z.), and the National Key Research and Development Program of China (2016YFC1200400 to Q.C.). QC is a scholar of New Century Excellent Talents in University of China.
\end{abstract}

\section{Author details}

${ }^{1}$ MOE\&NHC\&CAMS Key Laboratory of Medical Molecular Virology, School of Basic Medical Science, Shanghai Medical College, Fudan University, Shanghai 200032, P. R. China. ${ }^{2}$ State Key Laboratory of Environmental Chemistry and Ecotoxcicology, Research Center for Eco-Environmental Science, Chinese Academy of Sciences, Beijing 100085, P. R. China. ${ }^{3}$ Department of Gynecology, Key laboratory of AIDS immunology of Ministry of Health, First Affiliated Hospital of China Medical University, Shengyang 110000, P. R. China.

${ }^{4}$ ShengYushou Center of Cell Biology and Immunology, School of Life Sciences and Biotechnology, Shanghai Jiao Tong University, Shanghai 200240, P. R. China. ${ }^{5}$ Expert Workstation, Baoji Central Hospital, Baoji 721008, P. R. China

\section{Authors' contributions}

Q.C., F.W., C.W. and J.T. designed and oversaw the project; C.W. and J.T. performed experiments and collected data; J.Z., S.L. and F.W. provided materials; Y.G., Q.Z., D.L., F.G., J.G., C.Z. and Y.W. provided technical support; and C.W., J.T., F.W. and Q.C. wrote the manuscript.

Conflict of interest

The authors declare that they have no conflict of interest.

\section{Publisher's note}

Springer Nature remains neutral with regard to jurisdictional claims in published maps and institutional affiliations.

Received: 18 February 2019 Revised: 25 April 2019 Accepted: 2 May 2019 Published online: 21 May 2019

\section{References}

1. Galdiero, S. et al. Silver nanoparticles as potential antiviral agents. Molecules $\mathbf{1 6}$, 8894-8918 (2011).

2. Sun R. W., et al. Silver nanoparticles fabricated in Hepes buffer exhibit cytoprotective activities toward HIV-1 infected cells. Chem. Commun. (Camb) $\mathbf{4 0}$ 5059-5061 (2005).

3. Lara, H. H., Ayala-Nunez, N. V., Ixtepan-Turrent, L. \& Rodriguez-Padilla, C. Mode of antiviral action of silver nanoparticles against HIV-1. J. Nanobiotechnol. 8, 1 (2010).

4. Lara, H. H., Ixtepan-Turrent, L., Garza-Trevino, E. N. \& Rodriguez-Padilla, C. PVPcoated silver nanoparticles block the transmission of cell-free and cellassociated HIV-1 in human cervical culture. J Nanobiotechnol. 8, 15 (2010).

5. $L u, L$. et al. Silver nanoparticles inhibit hepatitis B virus replication. Antivir. Ther. 13, 253-262 (2008)

6. Baram-Pinto, D., Shukla, S., Gedanken, A. \& Sarid, R. Inhibition of HSV-1 attachment, entry, and cell-to-cell spread by functionalized multivalent gold nanoparticles. Small 6, 1044-1050 (2010). 
7. Baram-Pinto, D., Shukla, S., Perkas, N., Gedanken, A. \& Sarid, R. Inhibition of herpes simplex virus type 1 infection by silver nanoparticles capped with mercaptoethane sulfonate. Bioconjug. Chem. 20, 1497-1502 (2009).

8. Papp, I. et al. Inhibition of influenza virus infection by multivalent sialic-acidfunctionalized gold nanoparticles. Small 6, 2900-2906 (2010).

9. AshaRani, P. V., Low Kah Mun, G., Hande, M. P. \& Valiyaveettil, S. Cytotoxicity and genotoxicity of silver nanoparticles in human cells. ACS Nano 3, 279-290 (2009).

10. Nallathamby, P. D. \& Xu, X. H. Study of cytotoxic and therapeutic effects of stable and purified silver nanoparticles on tumor cells. Nanoscale 2, 942-952 (2010).

11. Zhang X. F., Liu Z. G., Shen W. \& Gurunathan S. Silver nanoparticles: synthesis, characterization, properties, applications, and therapeutic approaches. Int. J. Mol. Sci. 17, e1534 (2016).

12. Gurunathan, S. et al. Antiangiogenic properties of silver nanoparticles. Biomaterials 30, 6341-6350 (2009).

13. Kemp, M. M. et al. Gold and silver nanoparticles conjugated with heparin derivative possess anti-angiogenesis properties. Nanotechnology 20, 455104 (2009).

14. Liu, J. et al. TAT-modified nanosilver for combating multidrug-resistant cancer. Biomaterials 33, 6155-6161 (2012).

15. Sriram, M. I., Kanth, S. B., Kalishwaralal, K. \& Gurunathan, S. Antitumor activity of silver nanoparticles in Dalton's lymphoma ascites tumor model. Int. J. Nanomed. 5, 753-762 (2010).

16. Saha, A., Kaul, R., Murakami, M. \& Robertson, E. S. Tumor viruses and cancer biology Modulating signaling pathways for therapeutic intervention. Cancer Biol. Therapy 10, 961-978 (2010).

17. de Martel, C. et al. Global burden of cancers attributable to infections in 2008: a review and synthetic analysis. Lancet Oncol. 13, 607-615 (2012).

18. Young, L. S., Yap, L. F. \& Murray, P. G. Epstein-Barr virus: more than 50 years old and still providing surprises. Nat. Rev. Cancer 16, 789-802 (2016).

19. Reid, E. G. Bortezomib-induced Epstein-Barr virus and Kaposi sarcoma herpesvirus lytic gene expression: oncolytic strategies. Curr. Opin. Oncol. 23, 482-487 (2011).

20. Giffin, L. \& Damania, B. KSHV: pathways to tumorigenesis and persistent infection. Adv. Virus Res. 88, 111-159 (2014).

21. Dzeng, R. K. et al. Small molecule growth inhibitors of human oncogenic gammaherpesvirus infected B-cells. Mol. Oncol. 9, 365-376 (2015).

22. Andrei, G. \& Snoeck, R. Kaposi's sarcoma-associated herpesvirus: the role of Iytic replication in targeted therapy. Curr. Opin. Infect. Dis. 28, 611-624 (2015).
23. Pratsinis, A., Hervella, P., Leroux, J. C., Pratsinis, S. E. \& Sotiriou, G. A. Toxicity of silver nanoparticles in macrophages. Small 9, 2576-2584 (2013).

24. George, S. et al. Surface defects on plate-shaped silver nanoparticles contribute to its hazard potential in a fish gill cell line and zebrafish embryos. ACS Nano 6, 3745-3759 (2012)

25. Mao, B. H., Tsai, J. C., Chen, C. W., Yan, S. J. \& Wang, Y. J. Mechanisms of silver nanoparticle-induced toxicity and important role of autophagy. Nanotoxicology 10, 1021-1040 (2016).

26. Lee, Y. H. et al. Cytotoxicity, oxidative stress, apoptosis and the autophagic effects of silver nanoparticles in mouse embryonic fibroblasts. Biomaterials $\mathbf{3 5}$ 4706-4715 (2014).

27. Avalos, A., Haza, A. I., Mateo, D. \& Morales, P. Cytotoxicity and ROS production of manufactured silver nanoparticles of different sizes in hepatoma and leukemia cells. J. Appl. Toxicol. 34, 413-423 (2014).

28. Wang, Z, Xia, T. \& Liu, S. Mechanisms of nanosilver-induced toxicological effects: more attention should be paid to its sublethal effects. Nanoscale 7, 7470-7481 (2015).

29. Asharani, P. V., Hande, M. P. \& Valiyaveettil, S. Anti-proliferative activity of silver nanoparticles. BMC Cell Biol. 10, 65 (2009).

30. Verano-Braga, T. et al. Insights into the cellular response triggered by silver nanoparticles using quantitative proteomics. ACS Nano $\mathbf{8}, 2161-2175$ (2014).

31. Miethling-Graff, R. et al. Exposure to silver nanoparticles induces size- and dose-dependent oxidative stress and cytotoxicity in human colon carcinoma cells. Toxicol. In Vitro 28, 1280-1289 (2014).

32. Purushothaman, P., Uppal, T. \& Verma, S. C. Molecular biology of KSHV lytic reactivation. Viruses 7, 116-153 (2015).

33. Gillet, L., Frederico, B. \& Stevenson, P. G. Host entry by gammaherpesviruses-lessons from animal viruses? Curr. Opin. Virol. 15, 34-40 (2015).

34. Veettil, M. V., Bandyopadhyay, C., Dutta, D. \& Chandran, B. Interaction of KSHV with host cell surface receptors and cell entry. Viruses 6, 4024-4046 (2014).

35. da Silva, A. P. F. et al. Human gammaherpesviruses viraemia in HIV infected patients. J. Clin. Pathol. 68, 726-732 (2015).

36. Saghafian-Hedengren, S. et al. Epstein-Barr virus coinfection in children boosts cytomegalovirus-induced differentiation of natural killer cells. J. Virol. 87, 13446-13455 (2013)

37. Brulois, K. F. et al. Construction and manipulation of a new Kaposi's sarcomaassociated herpesvirus bacterial artificial chromosome clone. J. Virol. 86 9708-9720 (2012). 